\title{
SPATIAL DISTRIBUTION OF PHOSPHORUS IN THE SOIL AND SOYBEAN YIELD AS FUNCTION OF FERTILIZATION METHODS
}

\author{
DISTRIBUIÇÃO ESPACIAL DE FÓSFORO NO SOLO E PRODUTIVIDADE DA \\ SOJA EM FUNÇÃODOS MODOS DE ADUBAÇÃO
}

\author{
Newton Cabral BARBOSA ${ }^{1}$; Hamilton Seron PEREIRA ${ }^{2}$; Everton Martins ARRUDA ${ }^{1}$; \\ Elias BROD ${ }^{1}$; Risely Ferraz de ALMEIDA ${ }^{1}$ \\ 1.Campus Jatobá de Jataí, Universidade Federal de Goiás; 2. Instituto de Ciências Agrárias, Universidade Federal de Uberlândia
}

\begin{abstract}
The method of phosphate fertilization is a factor that may affect soil phosphorus availability, directly affecting soybean (Glycine max) yield. Thus, the objective this study evaluated combinations of phosphate fertilization methods on lateral and depth distribution of phosphorus (P) in the soil, as well as soybean yield. Experimental design was randomized blocks, 5x4x8 factorial with split plots, evaluated within each fertilization method: 100\% broadcast, $75 \%$ broadcast and $25 \%$ in the sowing furrow, $50 \%$ broadcast and $50 \%$ in the row, $25 \%$ broadcast and $75 \%$ in the sowing furrow, $100 \%$ in the sowing furrow and control (No P fertilization), with four replications. The P content was evaluated at the depths $0-5,5-10,10-15$ and $15-20 \mathrm{~cm}$ and in eight lateral distributions every $5 \mathrm{~cm}$ (starting between two rows, through the sowing furrow and finishing in the middle of the next row). The method of broadcasting $100 \%$ of phosphate fertilization did not present differences in the evaluations of lateral distribution for phosphorus content, however, the methods of phosphate fertilization 75 and $100 \%$ in the sowing furrow performed better at the depths 0-5 and 5-10 cm, exactly on central lateral distributions. Increased plant height and soybean yield were observed as the amount of phosphorus increased in sowing furrow instead of broadcast application.
\end{abstract}

KEYWORDS: Broadcast application. Phosphate fertilization. Sowing furrow. Glycine max.

\section{INTRODUCTION}

Phosphorus $(\mathrm{P})$ is the most limiting element for agricultural production in tropical soils due to its high adsorption at the clays (ARRUDA et al., 2015). Thus, phosphate fertilization methods can affect $P$ availability in the soil, and soybean (Glycine max) productivity.

Phosphate fertilizer application methods can be surface broadcast, with or without incorporation, sowing furrow, planting pits or band application (SOUSA et al., 2004). Among these, the usual fertilization method is characterized by the application of soluble P sources in the sowing furrow (NUNES et al., 2011), however, broadcast $P$ application with no incorporation is being done in several grain producing regions in Brazil, especially in the states of Goiás (BARBOSA et al., 2015).

The farmer is choosing broadcast phosphate fertilization due to greater operational by productivity in grain producing farms, in such a way that there will be no need to interrupt sowing to refill the fertilizer reservoir, but only the seed boxes, assuring greater speed in comparison to the conventional fertilization in the sowing furrow (GUARESCHI et al., 2008). Such systematization of grain production prioritizes regions where a second crop can be grown, favoring plants by the more effective use of water (NUNES et al., 2011).

Despite $\mathrm{P}$ application in the sowing furrow presents greater efficacy (ANGHINONI; BARBER,
1980; COSTA et al., 2009), when P content is above the critical level and the probability of responses by the crop are low or nil, yield losses have not been observed after broadcast application (PAVINATO; CERETTA, 2004; GUARESCHI et al., 2008), although the studies reporting the efficacy of such fertilization technique, especially in soybeans, are scant.

In general, an effective phosphate application method must supply $\mathrm{P}$ adequately to the soil, resulting in better placement and distribution, favoring plant root growth (ANGHINONI; BARBER, 1980; COSTA et al., 2009; COSTA et al., 2010). Also, it is important to understand the impacts of soil management on $\mathrm{P}$ dynamics since soil quality can be altered and, consequently, have implications on sustainability of agriculture (COSTA et al., 2014).

Thus, this study evaluated combinations of phosphate fertilization methods on lateral and in depth distribution of phosphorus in the soil, as well as soybean yield within each method.

\section{MATERIAL AND METHODS}

The experiment was done in agricultural year 2011, located in Jataí, southwest region in the state of Goiás, Brazil, at $17^{\circ} 83^{\prime} 96^{\prime \prime} \mathrm{S}$ and $51^{\circ} 63^{\prime} 49^{\prime \prime} \mathrm{W}, 700 \mathrm{~m}$ above sea level and average annual rainfall of 1800 $\mathrm{mm}$. The soil in the experimental area was classified as Dystrophic Yellow Red Latosol (EMBRAPA, 2013). 
The soil chemical properties in the $0,2 \mathrm{~m}$ layer before the experiment presented $\mathrm{P}$ (Anion exchange resin): 9,8 $\mathrm{mg} \mathrm{dm}{ }^{-3} ; \mathrm{Ca}^{2+}: 1,4 \mathrm{cmol}_{\mathrm{c}} \mathrm{dm}^{-3} ; \mathrm{Mg}^{2+}: 0,5 \mathrm{cmol}_{\mathrm{c}} \mathrm{dm}^{-3}$; $\mathrm{K}^{+}: 40 \mathrm{mg} \mathrm{dm}^{-3} ; \mathrm{H}+\mathrm{Al}: 7,5 \mathrm{cmol}_{\mathrm{c}} \mathrm{dm}^{-3} ; \mathrm{pH}\left(\mathrm{CaCl}_{2}\right)$ : 4,4; Organic matter: $16 \mathrm{~g} \mathrm{dm}^{-3}$; CEC: $9,52 \mathrm{cmol}_{\mathrm{c}} \mathrm{dm}^{-3}$; Base saturation: $21,05 \%$. The granulometric analysis presented 495, 100 and $405 \mathrm{~g} \mathrm{~kg}^{-1}$ of sand, silt and clay, respectively. This experiment was the first year of soybean cultivation in the area, which was previously a nature pasture that had received no fertilization through the years.

The experimental design was randomized blocks in $5 \times 4 \times 8$ factorial, with split plots, evaluated within each fertilization method. The factors in the plots were the fertilization methods, consisting of broadcast $\mathrm{P}$ fertilization with no incorporation, or in sowing furrow before soybean sowing, where: broadcasting $100 \%$ of fertilization, $75 \%$ broadcast and $25 \%$ in the sowing furrow, $50 \%$ broadcast and $50 \%$ in the row, $25 \%$ broadcast and $75 \%$ in the sowing furrow, $100 \%$ in the sowing furrow, and a control (No P fertilization). Soil phosphorus depths and lateral distribution were the subplots, with four replications. Depths evaluated were 0-5, 5-10, 10-15 and 15-20 cm and eight lateral distributions equidistant every $5 \mathrm{~cm}$ in the lateral $40 \mathrm{~cm}$ evaluated (starting in mid-row, passing through the sowing furrow and ending on the other mid-row). The plots were $10 \mathrm{~m}$ long and $3 \mathrm{~m}$ wide, in a total of $30 \mathrm{~m}^{2}$, from which $5,4 \mathrm{~m}^{2}$ were used for analysis and the total area of the experiment was $720 \mathrm{~m}^{2}$.

Soil was harrowed twice before planting with 32 -inch dented disks. Soil acidity was corrected with dolomitic limestone, $\mathrm{CaCO}_{3}$ equivalent total relative neutralization power (TRNP) of $70 \%$ at $3,500 \mathrm{~kg} \mathrm{ha}^{-1}$, containing $30 \% \mathrm{CaO}$ and $16 \% \mathrm{MgO}$, and a light harrowing was done to incorporation. Potassium fertilization was done by applying potassium chloride $\left(\mathrm{KCl}, \mathrm{K}_{2} \mathrm{O}\right.$ at $\left.100 \mathrm{~kg} \mathrm{ha}^{-1}\right)$ two days before sowing. The standard dose used in phosphate fertilization was monoammonium phosphate (MAP, $\mathrm{P}_{2} \mathrm{O}_{5}$ at $120 \mathrm{~kg} \mathrm{ha}^{-1}$ ), varying its proportion according to the application method, in the sowing row or broadcast. The fertilizer was weighed and placed in plastic bags to be applied manually according to distribution method.

The sowing furrows were opened with a planter fertilizer spreader for the treatments with sowing furrow fertilization. Then the grooves were closed for the application of treatments involving broadcast fertilization. Soybean sowing was done with cultivar Anta 82 RR, at a density of 555,000 seeds per hectare. Phytosanitary management was similar in all treatments.

Soil sampling started at mid-row, passing through the sowing furrow, and ending on the next mid-row. Sampling was done manually, with the aid of boards, as proposed by Schurman and Goedewaagen (1965). Each board (40x20x5 cm, length, width and thickness, respectively) was divided into four depths $(0-5,5-10,10-15,15-20 \mathrm{~cm})$ and lateral distributions of $5 \mathrm{~cm}(4 \times 8=32)$. In each monolith (board or square) soil as separated with spatulas and rulers for subsequent determination of $\mathrm{P}$ concentrations by the method of anion exchange resin (RAIJ et al., 1986).

Average soybean plant height was estimated, measuring 10 arbitrarily selected plants in each evaluation row of the plot. Harvest was done manually and, seed moisture was determined and adjusted to $13 \%$, and seed weight determined to obtain net yield $\left(\mathrm{kg} \mathrm{ha}^{-1}\right)$.

Statistical analysis of data was done by analysis of variance ( $F$ Test) and the averages compared by the Tukey test $(p<0.05)$, using statistical analysis system program (SISVAR), version 5.6 (FERREIRA, 2011).

\section{RESULTS AND DISCUSSION}

All treatments presented stratification, with strong reduction in $\mathrm{P}$ content as soil depth increased, regardless of combinations of application methods used (Figure1). Phosphorus stratification in the soil can occur in any fertilization method (COSTA et al., 2010; BARBOSA et al., 2015), however, it becomes expressive when broadcast fertilization methods are used (NUNES et al., 2011).

The control treatment, with no $\mathrm{P}$ applied to the soil, showed no significant difference in lateral distribution of the sowing furrow, which is justified by the lack of phosphate fertilization (Figure 1A).

Broadcasting $100 \%$ of the phosphate fertilization had no difference in the evaluations of $\mathrm{P}$ lateral distribution, explaining the absence of deposition zones due to the uniform distribution of the fertilizer over the soil surface (Figure 1B). In contrast, stratification on the soil profile, with greater concentration at the depth of $0-5 \mathrm{~cm}$, which was 10,37 and $56 \%$ greater in relation to the depths of 5-10, 10-15 and $15-20 \mathrm{~cm}$, respectively.

Phosphate fertilization with $75 \%$ broadcast and $25 \%$ in the sowing furrow had significant difference for lateral distribution at $0-5 \mathrm{~cm}$ depth, with greater values at the central $5 \mathrm{~cm}$ (positions 5 and zero), around the around the sowing furrow (Figure 1C). At this lateral position, At this lateral position, $\mathrm{P}$ values reached 65 $\mathrm{mg} \mathrm{dm}{ }^{-3}$, which was four times greater than the average values found in the adjacent lateral distribution, demonstrating that the application of just $25 \%$ of the fertilizer in the sowing furrow already accumulate in this region. 


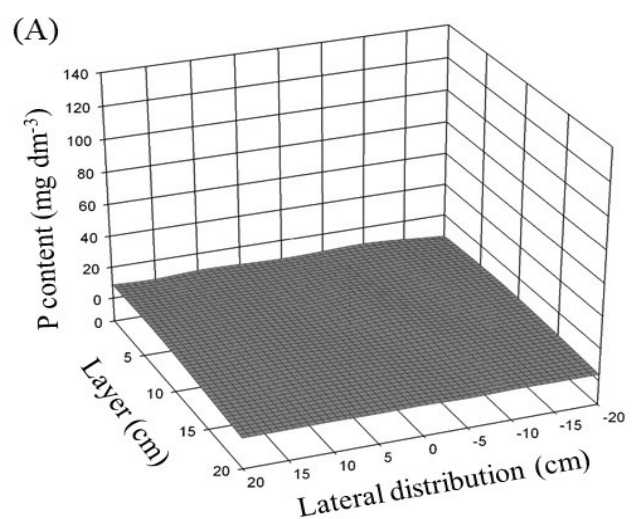

Control

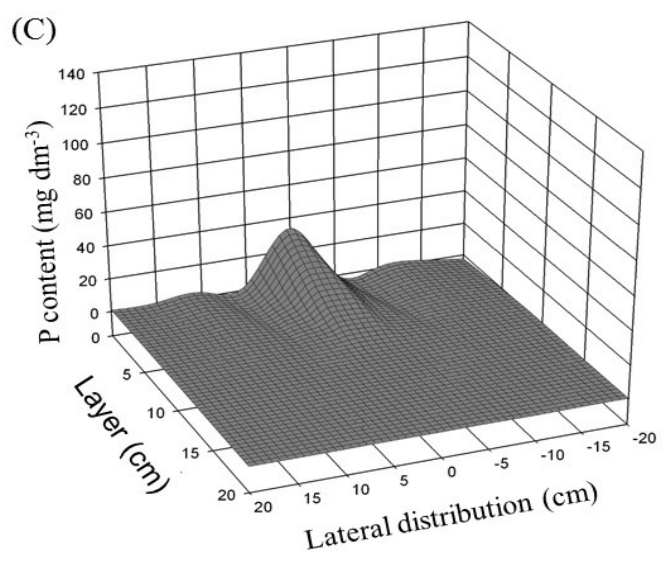

$75 \%$ broadcast and $25 \%$ sowing furrow

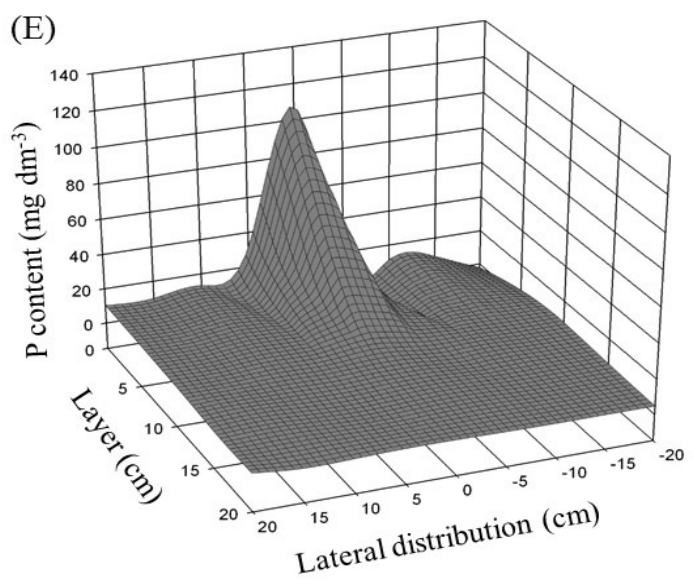

$25 \%$ broadcast and $75 \%$ sowing furrow

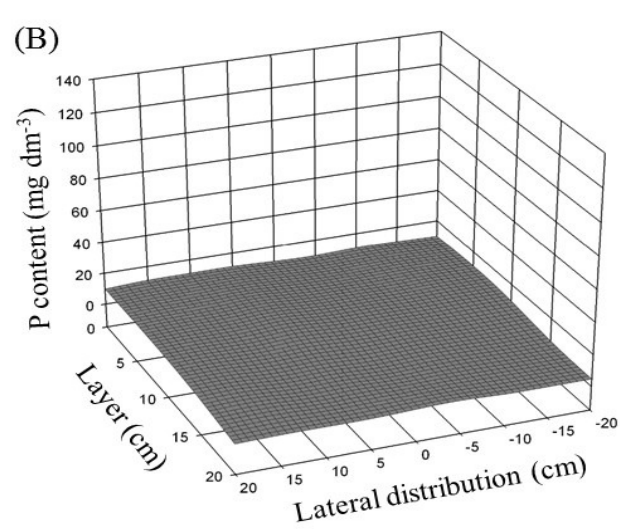

$100 \%$ broadcasting

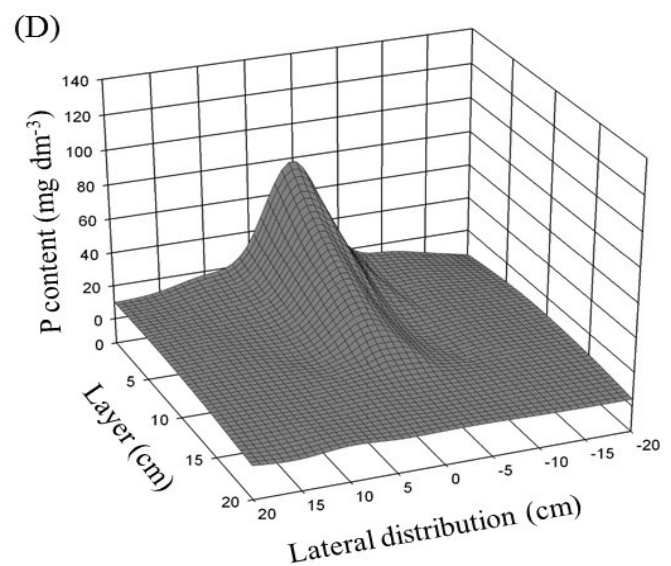

$50 \%$ broadcast and $50 \%$ sowing furrow

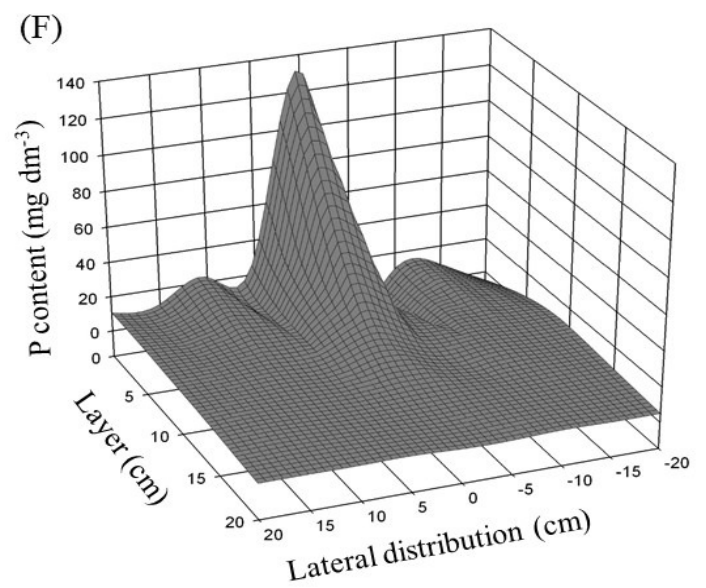

$100 \%$ sowing furrow

Figure 1. Lateral and vertical distribution of soil $\mathrm{P}$ as a function of combinations of distribution methods (Value zero corresponds to the sowing furrow)

Despite the advantages of these phosphate fertilization methods (75 and $100 \%$ broadcast) in relation to operational efficiency due to lower agricultural implement weight that do not load the fertilizer containers (GUARESCHI et al., 2008), thus reducing costs with diesel fuel and increasing sowing speed in both harvests (NUNES et al., 2011), such operational advantages are not sustainable for soybean production, since the formation of $\mathrm{P}$ concentration gradients at the surface layer $(0-5 \mathrm{~cm}$ depth $)$ can 
become a problem for plant development and the root system follows $P$ fertilization bands in the soil (COSTA et al., 2009), limiting root growth to the surface layer (COSTA et al., 2010). Possible consequences could by drought stress of the plants caused by dry spells in the region, restricting water and nutrient absorption (GREGORY, 2006; COSTA et al., 2010) and P losses due to sheet erosion (ANDRASKI et al., 2003), besides favoring greater susceptibility to pant lodging due to the restricted soil area used for root fixation (BARBOSA et al., 2015). Another negative factor is that most of the phosphate fertilizer will come into contact with soil, promoting $\mathrm{P}$ fixation and, consequently, lower absorption by plants (GUARESCHI et al., 2008).

Studies have reported that soil surface $\mathrm{P}$ levels three (DUIKER; BEEGLE, 2006) to tem times (BAYER; BERTOL, 1999) greater in systems that emphasize phosphate broadcast application. However, broadcast $\mathrm{P}$ applications can be done in specific cases, when soils present $\mathrm{P}$ contents above the critical levels or in no tillage production systems, where greater levels of organic matter are observed, or in conditions of successive phosphate fertilizations (BARBOSA et al., 2015 ) with doses above $100 \mathrm{~kg} \mathrm{ha}^{-1}$ de $\mathrm{P}_{2} 0_{5}$ (SOUSA et al., 2004).

Phosphate fertilization system with $50 \%$ broadcast and $50 \%$ in the sowing furrow presented had significant difference for lateral distribution at the depths $0-5$ and $5-10 \mathrm{~cm}$, with greater amounts in the middle $10 \mathrm{~cm}$ (between positions 5, zero and -5 ), exactly over the sowing furrow (Figure 1D). In these lateral distributions, average $\mathrm{P}$ contents reached 55, 75 and $19,39 \mathrm{mg} \mathrm{dm}^{-3}$, representing increases of 250 and $97 \%$ at the depths $0-5$ and $5-10 \mathrm{~cm}$, respectively, in relation to the averages observed in the adjacent lateral distributions.

The phosphate fertilization methods of 75 and $100 \%$ in the sowing row were better at the depths $0-5$ and 5-10 $\mathrm{cm}$ (Figures $1 \mathrm{E}$ and $1 \mathrm{~F}$ ). Soil $\mathrm{P}$ contents, at 0 $5 \mathrm{~cm}$ depth were 69,47 and $81,18 \mathrm{mg} \mathrm{dm}^{-3}$, representing increments of 5,2 and 5,4 times for the applications of 75 and $100 \% \mathrm{P}$ in the sowing furrow, respectively, in the center of the distribution bands (between positions 5 , zero and -5 ), in relation to the averages observed in adjacent distributions. Soil P contents, at 5-10 cm depth were 11,95 and $19,12 \mathrm{mg} \mathrm{dm}^{-3}$, representing increments of 27 and $90 \%$ for the applications of 75 and $100 \% \mathrm{P}$ in the sowing furrow, respectively, in the center of the distribution bands (between positions 5 and zero), in relation to the averages observed in adjacent distributions, exactly in the location of fertilizer deposition in the sowing furrow.

Increased $\mathrm{P}$ contents at the depth $0-5 \mathrm{~cm}$ and especially at the $5-10 \mathrm{~cm}$ central lateral positions are related to the location of phosphate fertilizer application in the sowing row, which is placed below the seeds, at an average depth of 6 to $8 \mathrm{~cm}$. This fertilization method tends to form $\mathrm{P}$ saturation zones of fertilizer application, contributing for increased soil $\mathrm{P}$ in this area (COSTA et al., 2010), concentrating at a maximum depth of $10 \mathrm{~cm}$ (COSTA et al., 2014). Other studies confirmed $\mathrm{P}$ accumulation caused by fertilization the sowing furrow at an average depth of 5$8 \mathrm{~cm}$ (COSTA et al., 2009; NUNES et al., 2011).

Below $10 \mathrm{~cm}$ depth, all phosphate fertilization combinations presented similar performances, demonstrating a decrease in $\mathrm{P}$ contents (Figures 1A, $1 \mathrm{~B}, 1 \mathrm{C}, 1 \mathrm{D}, 1 \mathrm{E}$ and $1 \mathrm{~F})$, which, in a certain manner, indicate little in depth effect of fertilization methods. Costa et al. (2009) observed the effect of P distribution in the soil profile only to $15 \mathrm{~cm}$ depth for application methods of broadcast, furrow and band.

In order to increase available $\mathrm{P}$ contents at depths below $10 \mathrm{~cm}$ in the soil profile, species with denser and more aggressive root systems could be used, since their subsequent decomposition will make $\mathrm{P}$ available at deeper layers where the roots had grown (GREGORY, 2006). Phosphorus redistribution in the soil profile is a consequence of its migration to deeper layers and can occur in response to organic decomposition of residues near the soil surface, or by root decomposition, thus increasing $\mathrm{P}$ contents (COSTA et al., 2014).

Soybean average height was significantly different among phosphate fertilization methods (Figure2). Total phosphate fertilization in the sowing furrow resulted on average height of $50,1 \mathrm{~cm}$, which was 17 and $24 \%$ greater than 75 and $100 \%$ phosphate broadcast fertilization, respectively. This high lights the importance of the best $\mathrm{P}$ location for plant growth. 


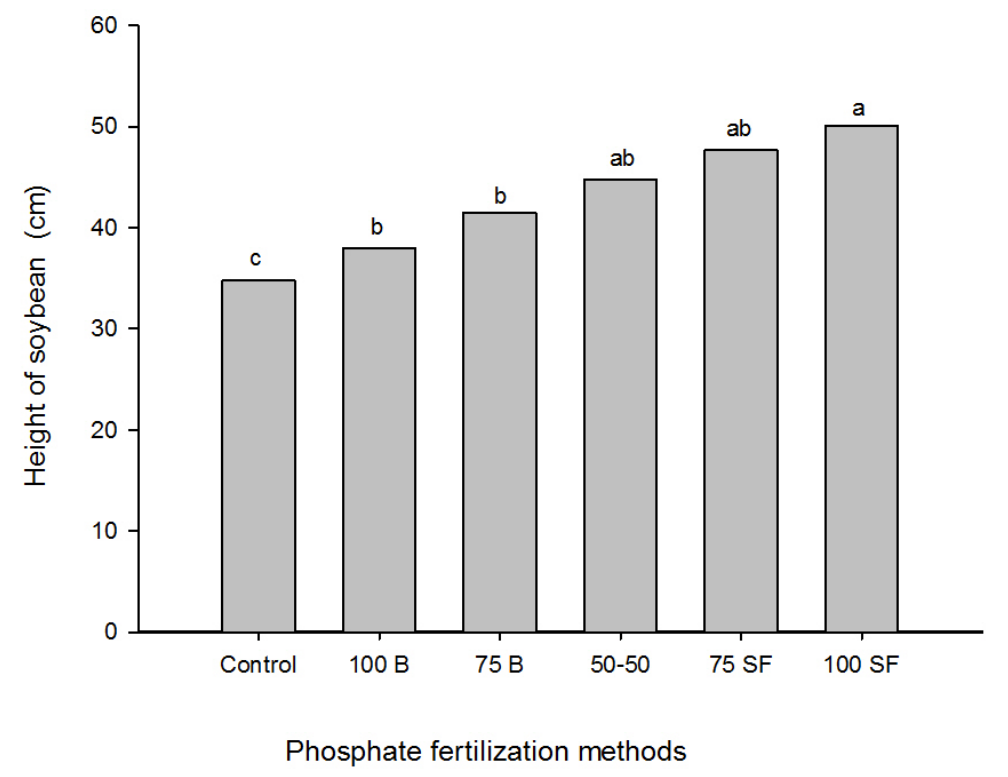

Figure 2. Soybean height in different phosphate fertilization methods in the Brazilian savannah. Averages followed by different letters are different by the tukey test $(p<0,05)$. Control: No P fertilization; 100 B: broadcasting $100 \%$ of fertilization; 75 B: $75 \%$ broadcast and $25 \%$ in the sowing furrow; $50-50$ : $50 \%$ broadcast and $50 \%$ in the row; 75 SF: $25 \%$ broadcast and $75 \%$ in the sowing furrow, $100 \%$ in the sowing furrow.

The control, which no P fertilization, had the smallest soybean height $(34,8 \mathrm{~cm})$. However, since $100 \%$ phosphate broadcast fertilization was not different from the control, it could be related to the low $\mathrm{P}$ mobility in the soil, since the element concentrated in the soil surface. Broadcast fertilization can limit root absorption ability in most soil depths (BARBOSA et al., 2015), since root development and $\mathrm{P}$ absorption by plants increase with increasing soil volume fertilized (COSTA et al., 2009).

Soybean grain yield was significantly different among phosphate fertilization methods (Figure 3), with greatest value $\left(2887,9 \mathrm{~kg} \mathrm{ha}^{-1}\right)$, intermediate $(2107,6$ to $2610,8 \mathrm{~kg} \mathrm{ha}^{-1}$ ) and smallest (less than 2107,6 $\mathrm{kg} \mathrm{ha}^{-1}$ ).

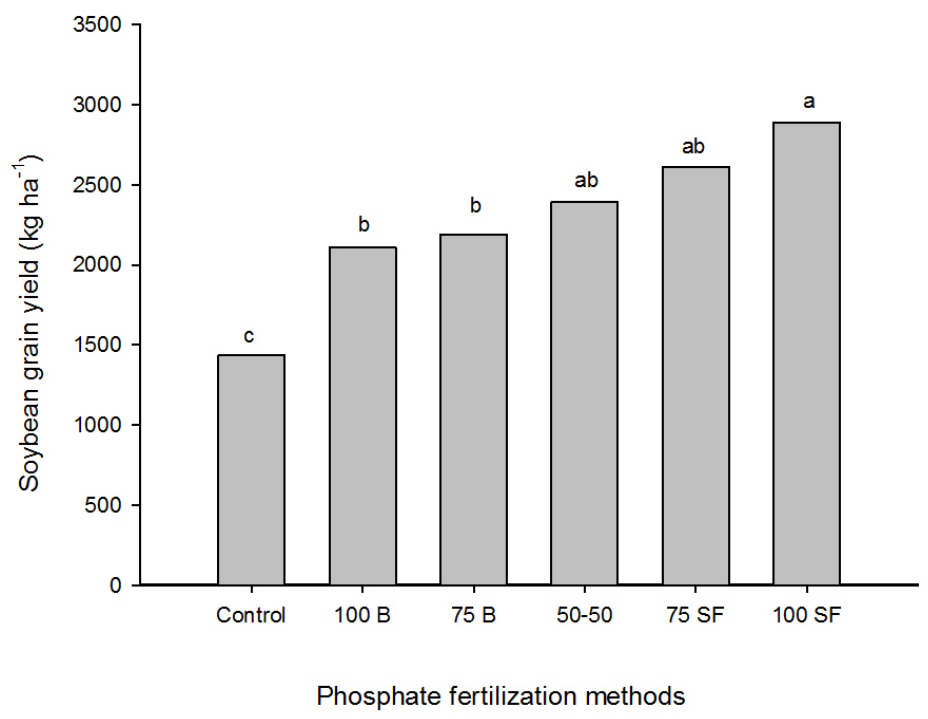

Figure 3. Soybean grain yield in different phosphate fertilization methods in the Brazilian savannah. Averages followed by different letters are different by the tukey test $(p<0,05)$. Control: No P fertilization; $100 \mathrm{~B}$ : broadcasting $100 \%$ of fertilization; 75 B: $75 \%$ broadcast and $25 \%$ in the sowing furrow; 50-50: $50 \%$ broadcast and 50\% in the row; 75 SF: $25 \%$ broadcast and $75 \%$ in the sowing furrow, $100 \%$ in the sowing furrow. 
The smallest yield was found in the control, with no $\mathrm{P}$ fertilization in a low natural fertility soil (SOUSA et al., 2004). Intermediate yield (2107,6 to $2610,8 \mathrm{~kg} \mathrm{ha}^{-1}$ ) was found in fertilization combined with broadcast application (25 to $100 \%$ ), with no significant differences, which was innovative since, within a broad band (25 to $100 \%$ ), P fertilization could be chosen with no yield loss. The greatest soybean grain yield was found when $100 \%$ of the phosphate dose was applied in the sowing furrow, which was 24 and $27 \%$ greater than 75 or $100 \% \mathrm{P}$ broadcast fertilization, respectively.

The study of Guareschi et al. (2008), in a Latosol of the savannah, showed no soybean yield difference for broadcast or sowing furrow $\mathrm{P}$ fertilization. Those authors attributed these results to soil fertility conditions in the study are, which were better than most savannah soils, where average $\mathrm{P}$ (Mehlich) levels are around $8,7 \mathrm{mg} \mathrm{dm}^{-3}$ (SOUSAet al., 2004). However, in those study conditions, in an area being cropped for the first time, increases in soybean height and yield were best when phosphate fertilization was done $100 \%$ in the sowing furrow, corroborating that the lower efficacy of broadcast $\mathrm{P}$ fertilization in relation to that in the sowing furrow is dependent on the initial level of this nutrient in the soil, resulting in lower $\mathrm{P}$ availability within root range and greater fixation of $\mathrm{P}$ to the soil after broadcast fertilization.

\section{CONCLUSION}

Soybean production in recently opened areas with low soils fertility should emphasize total $\mathrm{P}$ fertilization in the sowing furrow, in order to increase phosphorus content in depth and at adequate lateral distribution for greater benefit of soybean plants, which will respond with greater height and grain yield.

\section{ACKNOWLEDGEMENTS}

The authors would like to thank the following Brazilian institutions for their financial support: Coordination of Improvement of Higher Education Personnel (CAPES) and National Council for Scientific and Technological Development (CNPq).

RESUMO: O modo de adubação fosfatada é um fator que pode influenciar a disponibilização de fósforo no solo, afetando diretamente a produtividade das plantas de soja (Glycine max). O objetivo deste estudo foi avaliar combinações dos modos de adubação fosfatada na distribuição lateral e na profundidade de fósforo (P) no solo, assim como a produtividade da soja. O delineamento experimental foi em blocos casualizados, fatorial $5 \times 4 \times 8$ com parcelas subdividas, avaliadas dentro de cada modo de adubação: $100 \%$ a lanço, $75 \%$ a lanço e $25 \%$ na linha, $50 \%$ a lanço e $50 \%$ na linha, $25 \%$ a lanço e $75 \%$ na linha, $100 \%$ na linha e testemunha (sem fertilização P), com quatro repetições. Os teores de $\mathrm{P}$ foram avaliados nas profundidades de 0-5, 5-10, 10-15 e 15-20 cm e em oito distribuições laterais em espaçamento de 5 por $5 \mathrm{~cm}$ no solo (iniciando na entre linha, passando pela linha de plantio e indo até o meio da próxima entre linha). O modo de adubação fosfatada $100 \%$ a lanço não apresentou diferença nas avaliações de distribuição lateral para os teores de P, todavia, os modos de adubação fosfatada 75 e 100\% em linha de plantio apresentaram superioridade nas profundidades 0-5 e 5-10 cm, justamente em distribuições laterais centrais. Houve um aumento na altura e produtividade das plantas de soja conforme aumentava-se a quantidade de $\mathrm{P}$ na linha de plantio em detrimento a aplicação de $\mathrm{P}$ a lanço.

PALAVRAS-CHAVE: Aplicação a lanço. Adubação fosfatada. Linha de plantio. Glycine max.

\section{REFERENCES}

ANDRASKI, T. W.; BUNDY, L. G.; KILIAN, K. C. Manure history and long-term effects on soil properties and phosphorus losses in runoff. Journal of environmental quality, Madison, v. 32, n. 5, p. 1782-1789, 2003.

ANGHINONI, I.; BARBER, S. A. Phosphorus application rate and distribution in the soil and phosphorus uptake by corn. Soil Science Society of America Journal, Madison, v. 44, n. 5, p. 1041-1044, 1980.

ARRUDA, E. M.; LANA, R. M. Q.; PEREIRA, H. S. Fósforo extraído por mehlich I e resina de troca aniônica em solos submetidos á calagem. Bioscience Journal, Uberlândia, v. 31, n. 4, p. 1107-1117, 2015.

https://doi.org/10.14393/BJ-v31n4a2015-22170

BAYER, C.; BERTOL, I. 1999. Características químicas de um Cambissolo húmico afetadas por sistemas de preparo com ênfase na matéria orgânica. Revista Brasileira de Ciência do Solo, Viçosa, v. 23, n. 3, p. 867694, 1999. 
BARBOSA, N. C.; ARRUDA, E. M.; BROD, E.; PEREIRA, H. S. Distribuição vertical do fósforo no solo em função dos modos de aplicação. Bioscience Journal, Uberlândia, v. 31, n. 1, p. 87-95, 2015.

https://doi.org/10.14393/BJ-v31n1a2015-18196 https://doi.org/10.14393/BJ-v31n1a2015-18196-

COSTA, S. E. V. G. A.; SOUZA, E. D.; ANGHINONI, I.; FLORES, J. P. C.; CAO, E. G.; HOLZSCHUH, M. J. Phosphorus and root distribution and corn growth as related to long-term tillage systems and fertilizer placement. Revista Brasileira de Ciência do Solo, Viçosa, v. 33, n. 5, p. 1237-1247, 2009.

COSTA, S. E. V. G. A.; SOUZA, E. D.; ANGHINONI, I.; FLORES, J. P. C.; VIEIRA, F. C. B.; MARTINS, A. P.; FERREIRA, E. V. O. Patterns in phosphorus and corn root distribution and yield in long-term tillage systems with fertilizer application. Soil and Tillage Research, Amsterdam, v. 109, n. 101, p. 41-49, 2010. https://doi.org/10.1016/j.still.2010.04.003

COSTA, S. E. V. G. A.; SOUZA, E. D.; ANGHINONI, I.; CARVALHO, P. C. F.; MARTINS, A. P.; KUNRATHC, T. R.; CECAGNOA, D.; BALERINI, F. Impact of an integrated no-till crop-livestock system on phosphorus distribution, availability a nd stock. Agriculture, Ecosystems and Environment, Amsterdam, v. 190, n. 1, p. 43-51, 2014. https://doi.org/10.1016/j.agee.2013.12.001

DUIKER, S. W.; BEEGLE, D. B. Soil fertility distributions in long-term no-till, chiseldisk and moldboard plow disk systems. Soil and Tillage Research, Amsterdam, v. 88, n. 1, p. 30-41, 2006.

https://doi.org/10.1016/j.still.2005.04.004

EMBRAPA - Empresa Brasileira de Pesquisa Agropecuária. Sistema Brasileiro de classificação de Solos. 3. ed. Rio de Janeiro: Embrapa Solos, 2013, 350 p.

FERREIRA, D. F. SISVAR: Um programa para análises e ensino de estatística. Revista Symposium, Campinas, v. 6, n. 2, p. 36-41, 2011.

GUARESCHI, R. F.; GAZOLLA, P. R.; SOUCHIE, E. L.; ROCHA, A. C. Adubação fosfatada e potássica na semeadura e a lanço antecipada na cultura da soja cultivada em solo de Cerrado. Semina: Ciências Agrárias, Londrina, v. 29, n. 4, p. 769-774, 2008. https://doi.org/10.5433/1679-0359.2008v29n4p769

GREGORY, P. Plant roots-growth, activity and interaction with soils. Oxford: lackwell Publishing, 2006, $318 \mathrm{p}$.

NUNES, R. S.; SOUSA, D. M. G.; GOEDERT, W. J.; VIVALDI, L. J. Distribuição de fósforo no solo em razão do sistema de cultivo e manejo da adubação fosfatada. Revista Brasileira de Ciência do Solo, Viçosa, v. 35, n. 3, p. 877-888, 2011.

PAVINATO, P. S.; CERETTA, C. A. Fósforo e potássio na sucessão trigo/milho: épocas e formas de aplicação. Ciência Rural, Santa Maria, v. 34, n. 6, p. 1779-1784, 2004. https://doi.org/10.1590/S010384782004000600017

RAIJ, B. V.; QUAGGIO, J. A.; SILVA, N. M. Extraction of phosphorus, potassium, calcium, and magnesium from soils by an ion-exchange resin procedure. Communications in Soil Science and Plant Analysis, Philadelphia, v. 17, p. 547-566, 1986. https://doi.org/10.1080/00103628609367733

SCHURMAN, J. J.; GOEDEWAAGEN, M. A. J. Methods for the examination of root systems and roots. 2. ed. Wageningen: Blackwell Publishing, 1965. 86 p.

SOUSA, D. M. G.; LOBATO, E.; REIN, T. A. Adubação com fósforo. In: SOUSA, D. M. G.; LOBATO, E. 2 ed. Cerrado: Correção do solo e adubação. Planaltina, Embrapa Cerrados, 2004, p. 147-168. 